\title{
Glacier and snow variations and their impacts on regional water resources in mountains
}

\author{
DENG Haijun ${ }^{1,2,3,4}$, CHEN Yaning ${ }^{3}$, LI Yang ${ }^{5}$
}

1. Fujian Provincial Engineering Research Center for Monitoring and Assessing Terrestrial Disasters, Fuzhou 350007, China;

2. State Key Laboratory Breeding Base of Humid Subtropical Mountain Ecology, Fuzhou 350007, China;

3. State Key Laboratory of Desert and Oasis Ecology, Xinjiang Institute of Ecology and Geography, CAS, Urumqi 830011, China;

4. College of Geographical Sciences, Fujian Normal University, Fuzhou 350007, China;

5. Nuclear and Radiation Safety Center, Beijing 100082, China

\begin{abstract}
Glaciers and snow are major constituents of solid water bodies in mountains; they can regulate the stability of local water sources. However, they are strongly affected by climate change. This study focused on the Tianshan Mountains, using glacier and snow datasets to analyse variations in glaciers, snow, water storage, and runoff. Three typical river basins (Aksu, Kaidou, and Urumqi Rivers) were selected to interpret the impacts of glacier and snow changes on regional water resources in the Tianshan Mountains. The results exhibited a nonlinear functional relationship between glacial retreat rate and area, demonstrating that small glacial retreat is more sensitive under climate change. Further, the glacial retreat rate at the low-middle elevation zone was seen to be faster than that at the high elevation zone. The regional average terrestrial water storage (TWS) decrease rate in the Tianshan Mountains was $-0.7 \pm 1.53 \mathrm{~cm} /$ a during 2003-2015. The highest TWS deficit region was located in the central part of the Tianshan Mountains, which was closely related to sharp glacial retreats. The increases in glacier and snow meltwater led to an increase in runoff in the three typical river basins, especially that of the Aksu River $\left(0.4 \times 10^{8} \mathrm{~m}^{3} / \mathrm{a}\right)$. The decreasing and thinning of areas, and increasing equilibrium line altitude (ELV) of glaciers have been the major causes for the decrease in runoff in the three river basins since the mid-1990s. Therefore, the results reveal the mechanisms causing the impacts of glaciers and snow reduction in mountains on regional water resources under climate change, and provide a reference for water resources management in the mountainous river basins.
\end{abstract}

Keywords: climate change; water resources; glacier and snow; cryosphere; Tianshan Mountains

\section{Introduction}

Global warming has driven and will continue to drive glacial retreat and influence regional

Received: 2018-05-05 Accepted: 2018-06-08

Foundation: National Natural Science Foundation of China, No.41807159

Author: Deng Haijun (1987-), PhD, specialized in climate and hydrological processes in mountains.

E-mail: denghj@fjnu.edu.cn 
water resources in mountains (Hansen et al., 2006; Immerzeel et al., 2010; Jacob et al., 2012; Lutz et al., 2014; MRI, 2015), and it is also a great concern to society. Glacial retreat and snowmelt in mountains will limit water resources utilization (Immerzeel et al., 2010; Chen et al., 2017) due to both glacial retreat (Shen et al., 2009; Gao et al., 2010) and the terrestrial water storage deficit (Deng and Chen, 2017); and more solar radiation will be absorbed due to the reduction in surface albedo caused by the decrease in glacier and snow coverage. This will then cause rapid cryosphere warming, further intensifying ablation and snowmelt (MRI, 2015).

Calculating terrestrial water storage (TWS) in mountains is a challenge because observation stations are sparse and records are short, therefore, most mountain regions have no data. The traditional method of estimating TWS uses the water balance equation $(\Delta \mathrm{S}=\mathrm{P}-\mathrm{E}-\mathrm{R}$, where $\Delta \mathrm{S}$ is water storage, $\mathrm{P}$ is precipitation, $\mathrm{E}$ is evapotranspiration, and $\mathrm{R}$ is runoff), however, this is limited by observation data. Therefore, using this method to estimate TWS in basins with no data increases uncertainty. In March 2002, the United States and Germany collaborated to develop and launch the gravity recovery and climate experiment (GRACE) satellite mission (http://www.csr.utexas.edu/grace/) to provide all-weather, continuous, and high resolution datasets for calculating TWS. Since GRACE's launch, the data it has produced has been widely used in hydrological research, for example, for analyzing variations in TWS (Schmidt et al., 2006; Xavier et al., 2010; Lee et al., 2011), monitoring glacier mass balance (Matsuo and Heki, 2010), estimating evapotranspiration (Rodell et al., 2004), determining changes in groundwater (Rodell et al., 2009), and monitoring droughts (Chen et al., 2005).

The Tianshan Mountains are located in the innermost part of the Eurasian continent, stretching for roughly $2500 \mathrm{~km}$ from east to west, and spanning averagely from $250 \mathrm{~km}$ to $350 \mathrm{~km}$ in a north-south direction (Chen et al., 2016). It endures more precipitation than the surrounding desert area due to westerly water vapour (Yao et al., 2013). Glaciers are widespread in this region, constituting one of the main glacial areas in the mid-latitude zone. It also protects water resources for socio-economy, oasis agriculture, and the eco-environment in Central Asia (Chen et al., 2016). The glaciers are mainly distributed between $2800 \mathrm{~m}$ and $7400 \mathrm{~m}$, covering a total area of roughly $13,566.6 \mathrm{~km}^{2}$ with a volume of approximately 1840 $\mathrm{km}^{3}$ (Aizen et al., 2008). Glaciers have been retreating due to warming over the past 50 years (Farinotti et al., 2015). Since the 1970s, the glacial area of the Tianshan Mountains has decreased by $8.5 \%$ (Aizen et al., 2011), but there are significant regional differences (Chen et al., 2016). Glacial retreat has affected the hydrological characteristics of rivers, water resources, the eco-environment, and socio-economic development in Central Asia.

In this study, we focus on climate change in mountains and its impact on their hydrologic process. First, we describe the spatio-temporal variations of glaciers and snow in the Tianshan Mountains (see sections 4.1 and 4.2). We then analyse the influence of glaciers and snow melt on regional water resources. Section 2 describes the study area, data, and methods. Section 3 describes the theory of this study. Section 4 focuses on variations in glacier and snow cover and their impact on water resources, and section 5 presents our conclusions.

\section{Methods}

\subsection{Study area}

The Tianshan Mountains lie in the heartland of Eurasia within $37^{\circ} \mathrm{N}-46^{\circ} \mathrm{N}$ and $66^{\circ} \mathrm{E}-96^{\circ} \mathrm{E}$ 
(Figure 1). The mountains cover numerous climatic vertical zones with a large glacier area. The types of glaciers in the Tianshan Mountains range from large valley and dendritic glaciers to small lobes and niche glaciers (Aizen et al., 2011). Large valley glaciers form $82 \%$ of the total glacial area. According to the latest World Catalogue of Glaciers (RGI 5.0) (Pfeffer et al., 2014), there are 10,778 glaciers in the Tianshan Mountains, covering a total area of approximately $13,566.6 \mathrm{~km}^{2}$, of which the largest single glacial area is $373.92 \mathrm{~km}^{2}$, and the smallest single glacial area is only $0.079 \mathrm{~km}^{2}$. The single longest glacier is $61445 \mathrm{~m}$, and the single shortest glacier is only $230 \mathrm{~m}$. There are 8264 glaciers covering less than 1 $\mathrm{km}^{2}$, accounting for $76.67 \%$ of the total number of glaciers; 2397 with an area of $1-10 \mathrm{~km}^{2}$, accounting for $22.23 \%$ of the total number of glaciers; 110 with an area of $10-100 \mathrm{~km}^{2}$; and only seven covering an area larger than $100 \mathrm{~km}^{2}$. Therefore, small glaciers predominate the Tianshan Mountains. In this study, we selected the Aksu, Kaidu, and Urumqi river basins as typical examples (Figure 1). The common feature of these basins is that they all originate from glaciers and snow-covered regions, and glacier and snowmelt accounts for a large proportion of river runoff. There are also large areas of cultivated land in the downstreams of these rivers (Xu et al., 2013). The studied basins are representative of the arid region of northwest China.

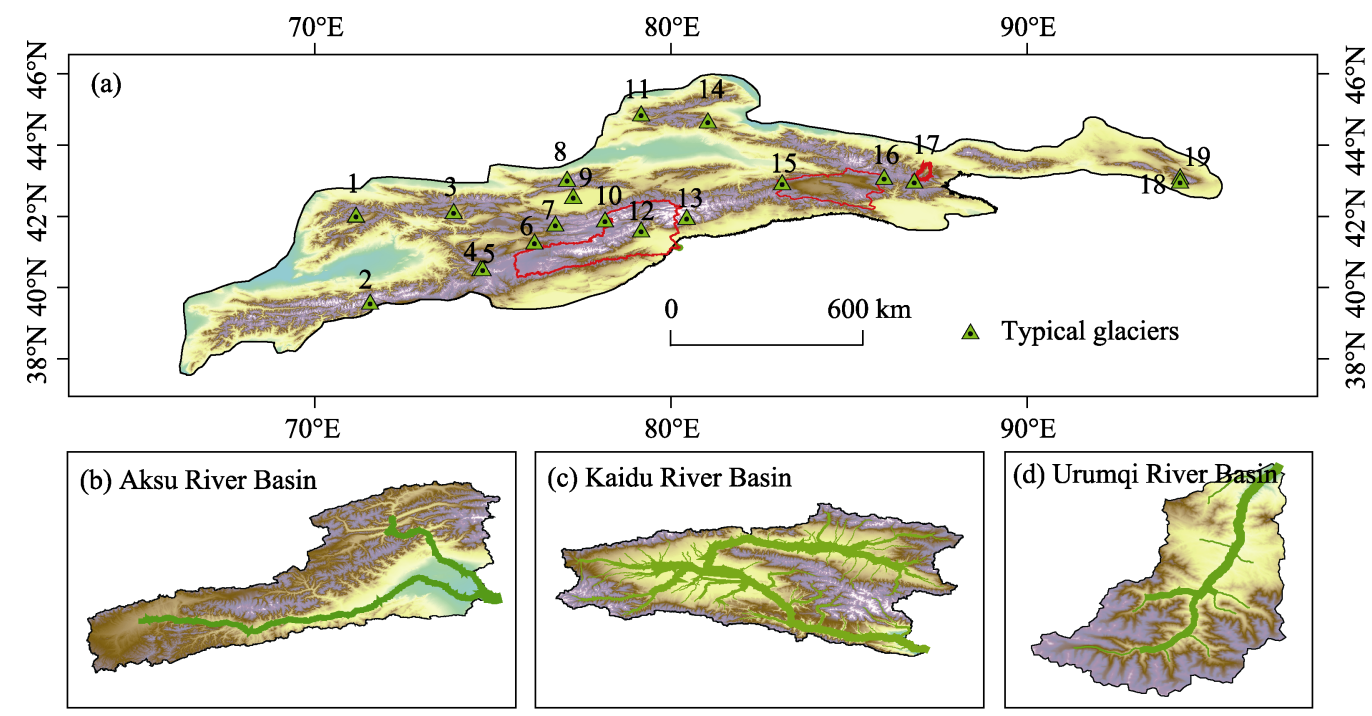

Figure 1 The Tianshan Mountains

\subsection{Data}

\subsubsection{Glaciers and snow data}

The glacial area data were obtained from the latest Randolph Glacier Inventory dataset RGI 5.0 (Pfeffer et al., 2014), and the glacial mass balance data from 1961 to 2010 were obtained from the literature (Farinotti et al., 2015). In addition, the glacial area change data of 19 typical watersheds (or glaciers) were gathered from literature (Narama et al., 2010; Zemp et al., 2012; Hagg et al., 2013; Kriegel et al., 2013; Wang et al., 2013; Zemp et al., 2013; Barandun et al., 2014; Xie and Jiang, 2014; He et al., 2015; Huai et al., 2015; Kaldybayev et al., 2016). The glacier area change data in the Aksu, Kaidu, and Urumqi river basins were derived from the China Glacier Inventory (CGI) of the West Data Central (Guo et al., 2014; 
Liu et al., 2015) (availableat http://westdc.westgis.ac.cn/).

The snow cover data from 2001 to 2013 were derived from the MODIS/Terra Snow Cover 8-Day L3 product (MOD10A2, version 5) with a spatial resolution of $500 \mathrm{~m}$, which is provided by the NASA Snow and Glacier Data Centre (http://dx.doi.org/10.5067/ C574UGKQQU1T).

\subsubsection{GRACE data}

The GRACE data were provided by the Jet Propulsion Laboratory (JPL, available at https:/grace.jpl.nasa.gov/data/get-data/jpl_global_mascons/) of the California Institute of Technology. In this study, the datasets are gridded at $0.5^{\circ} \times 0.5^{\circ}$, and they cover a time range from January 2003 to December 2015. Data for 13 months were missing (June 2003; January and June 2011; May and October 2012; March, August, and September 2013; February and December 2014; June, October, and November 2015), which were interpolated based on the multi-year cumulative averages of the missing months and adjacent months (Long et al., 2015).

\subsubsection{Runoff data}

The monthly runoff data from 1960-2010 used here were provided by the hydrological stations in the three river basins (Figure 1), specifically, the Sharikilank and Xiehera stations in the Aksu River Basin, the Dashankou station in the Kaidu River Basin, and the Yingxiongqiao station in the Urumqi River Basin.

\subsection{Analytical methods}

\subsubsection{Mann-Kendal nonparametric tests}

In this study, Mann-Kendal (M-K) nonparametric tests were applied to assess the significance of air temperature, precipitation, snow cover, and terrestrial water storage (TWS) trends in the Tianshan Mountains (Hirsch and Slack, 1984). The slope of a trend was estimated using Sen's nonparametric trend estimator (Sen, 1968).

\subsubsection{Terrestrial water storage calculation}

The method of retrieving variations in TWS from the GRACE data can be divided into two stages: the first stage is 2002-2013, and the standard spherical harmonic method (Wahr and Molenarr, 1998) is the most commonly used method. This method inputs the global observation data from gravity satellites into a gravity model (Zou et al., 2016), and then calculates variations in TWS. After this, a new method, the Mascons (mass concentration blocks) approach (for details see Watkins et al., 2015), was followed to calculate the variations in TWS based on the variability in the inter-satellite distance (Watkins et al., 2015). The characteristics of this method are helpful for eliminating noise originating outside of the region of interest (ROI) (Guo et al., 2014; Zou et al., 2016).

The Mascons approach was also used to calculate the changes in TWS in the Tianshan Mountians during 2003-2015. The Earth's oblateness scales (C20) coefficients were replaced to reduce uncertainty from the native GRACE-C20 values (Chen et al., 2005; Cheng et al., 2013), and the degree-1 coefficients were estimated using the method presented by Swenson (2008). A glacial isostatic adjustment (GIA) correction was then applied to the model (Geruo et al., 2013) to remove glacial rebound effects, especially in mountainous regions and high-latitude areas. The data anomalies' base period is from January 2004 to December 2009, because there are no missing values in this period. Finally, the scaling factors were applied 
to the data covering the study area, and the scale-corrected time series was calculated as follows:

$$
g^{\prime}(x, y, t)=g(x, y, t) * s(x, y)
$$

where $x$ is longitude, $y$ is latitude, $t$ is time (months), $g(x, y, t)$ is the grid surface mass change value, and $s(x, y)$ is the scaling grid. The scaling factors are provided by the JPL's website (https://grace.jpl.nasa.gov/data/get-data/jpl_global_mascons/).

The uncertainty estimates approach used in this study is described in Wahr et al. (2006).

\subsubsection{CV value}

The coefficient of variation ( $\mathrm{CV}$ value) for runoff volumeis an important indicator when evaluating the inter-annual variability of runoff $(\mathrm{Li}, 1982)$. The $\mathrm{CV}$ value is closely related to the variability of precipitation. In general, small $\mathrm{CV}$ values occur in humid areas, and larger CV values occur in arid and semi-arid areas.

\section{Theoretical framework}

Mountainous areas are unique geographical units that play an important role in natural regional environmental change. Modern glaciers are well-established and act as "water towers", providing water resources protection for the eco-environmental and socio-economic development in mountainous and downstream areas (Immerzeel et al., 2010). Glaciers and snow buffer the hydrological processes in mountain basins (Deng et al., 2017), regulating the instability of runoff caused by variability in precipitation. The main characteristic of global climate change is the significant increase in temperature since the mid-20th century, which has accelerated the melting of snow and ice in mountainous areas (Liu et al., 2003; Aizen, 2011; Jacob et al., 2012; Farinotti et al., 2015; Paul et al., 2015). Thus, mountain regions have received worldwide attention.

The theoretical framework of this paper is based on the relationship of the "Atmosphere-Cryosphere-Hydrosphere" to explore the mechanisms causing the impact of climate change on regional water resources in mountainous areas. As shown in Figure 2, the process can be divided as follows:

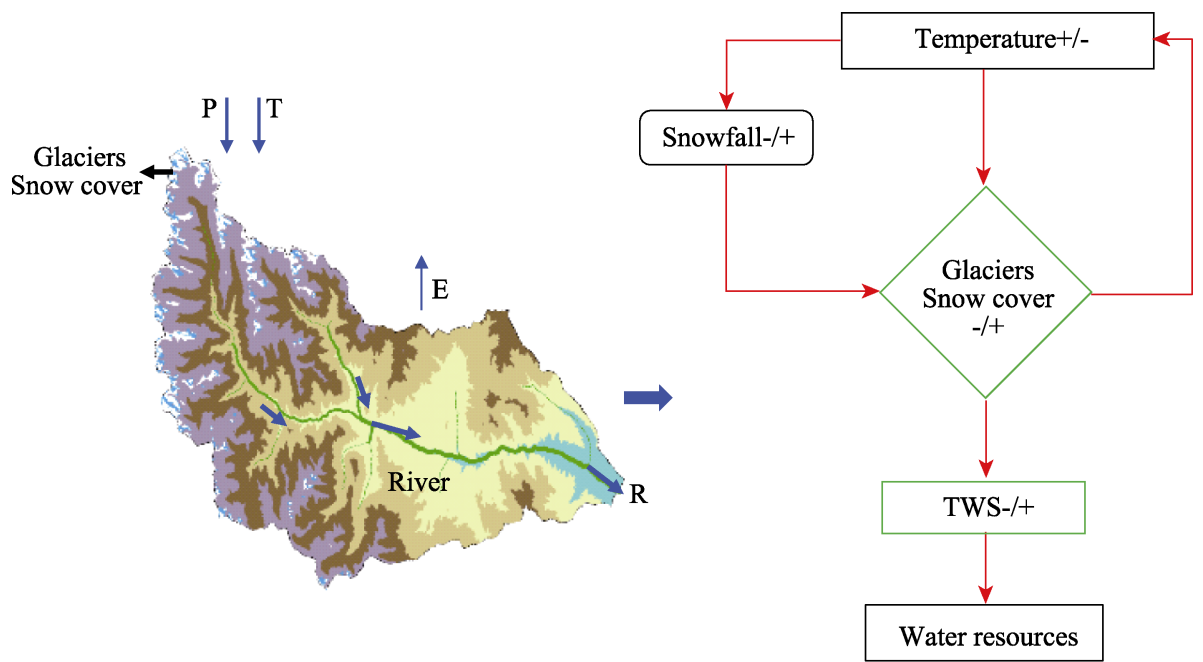

Figure 2 Sketch map of the theoretical framework in this study (P: precipitation, T: temperature, E: evapotranspiration, R: runoff, and TWS: terrestrial water storage) 
(1) If the mountainous areas are dominated by warming, the form of precipitation will change from snowfall to rainfall (Berghuijs et al., 2014; Deng et al., 2017), so snowfall will decrease, leading to a decrease in material sources for the accumulation of glaciers and snowpack. At the same time, the increasing temperatures have also directly accelerated glacial and snow melting in mountains. These results cause glacier and snow ablation in the mountainous areas to increase beyond the accumulation rate, causing mountain water storage to decrease, further affecting the water resources in the river basin. In addition, the melting of glaciers and snow will reduce the albedo in the original glaciers and snow-covered areas, thereby increasing the absorption of solar radiation and accelerating the increase in temperature and melting of glaciers and snow in the mountains. Therefore, this process amplifies warming in the mountainous areas.

(2) If the mountainous areas are dominated by cooling, snowfall will increase, and suppress glacier and snow ablation, causing the accumulation of solid water bodies in mountainous areas to increase beyond the ablation. Meanwhile, the albedo will also increases as the glaciers and snow-covered areas increases, which would decrease the amount of solar radiation absorbed by the cryosphere, slow the rate of temperature increase in the mountainous areas, and suppress glacier and snow melting in the mountains. Therefore, this process suppresses warming in the mountains.

\section{Results and discussion}

\subsection{Glacier changes}

Glacial retreat differs significantly at different elevations. Figure $3 a$ shows that the glacial retreat rate decreased as elevation increased owing to the lower temperature at higher elevations. The highest glacial retreat rate is $-2.3 \times 10^{3} \mathrm{~kg} /\left(\mathrm{m}^{2} \cdot \mathrm{a}\right)$, which occurred below $3000 \mathrm{~m}$ (Figure 3a). The glacial retreat rate at $3000-4000 \mathrm{~m}$ is approximately $-0.610^{3} \mathrm{~kg} /\left(\mathrm{m}^{2} \cdot \mathrm{a}\right)$. The glacier retreat rate at $4000-5000 \mathrm{~m}$ is approximately $-0.3 \times 10^{3} \mathrm{~kg} /\left(\mathrm{m}^{2} \cdot \mathrm{a}\right)$, and that above $5000 \mathrm{~m}$ is very small (Figure 3a). Therefore, the area between $3000 \mathrm{~m}$ and $4000 \mathrm{~m}$ should be a key monitoring region for the glacial mass balance, because most glaciers are distributed in this region in the Tianshan Mountains (Chen et al., 2016).
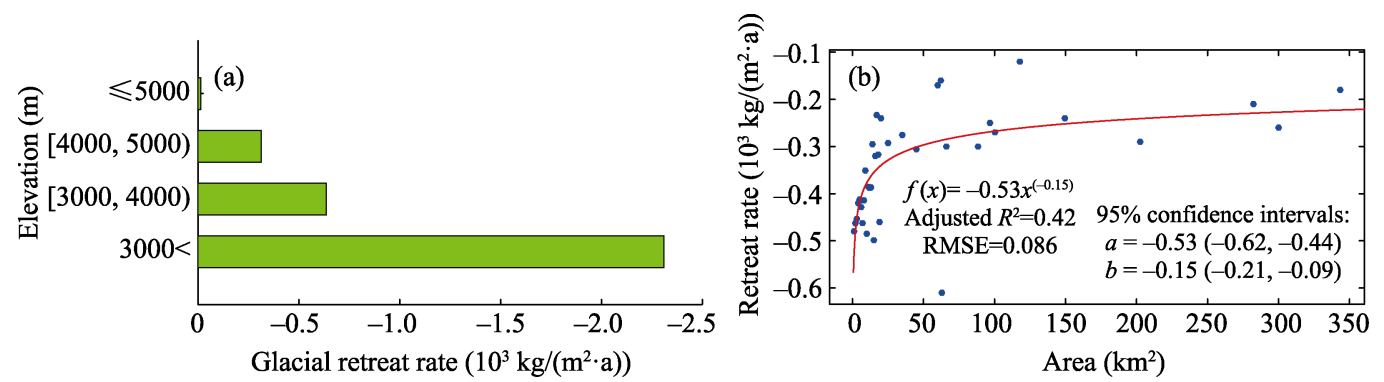

Figure 3 Glacier variations in the Tianshan Mountains during 1961-2012 (datasets provided by Farinotti et al., 2015), (a) the glacial retreat rate at different elevation bands; (b) the glacial retreat rate in different areas fitted with the function $f(x)=a \times x^{b}$.

Different glaciers exhibit different response levels to climate change. To understand the relationship between glacier area and retreat rate, the glacier area was divided into different 
grades. These grades are as follows: glaciers smaller than $10 \mathrm{~km}^{2}$ had $1 \mathrm{~km}^{2}$ per grade, because most glaciers were within this range; glaciers between $10 \mathrm{~km}^{2}$ and $50 \mathrm{~km}^{2}$ had $10 \mathrm{~km}^{2}$ per grade, and glaciers larger than $50 \mathrm{~km}^{2}$ were not classified. The average rate of glacial retreat for each grade was then calculated, and the relationship between glacier area and retreat rate was fitted by exponential function $f(x)=a \times x^{b}$ (where $x$ is the glacier area, and $a$ and $b$ are fitting parameters). The function fitting result is $f(x)=-0.53 \times x^{-0.15}$, the $95 \%$ confidence intervals for $a$ and $b$ are $-0.53(-0.62,-0.44)$ and $-0.15(-0.21,-0.09)$, respectively, the adjusted $R^{2}$ is 0.42 , and the RMSE is 0.086 . This indicates that the function fitting result is good, and the functional relationship demonstrates that the glacial retreat rate is inversely related to glacier area (Figure $3 b$ ). That is, small glaciers are more sensitive to climate change, while large glaciers are relatively stable. For glaciers larger than $50 \mathrm{~km}^{2}$, the retreat rate is stable at $-0.3 \times 10^{3} \mathrm{~kg} /\left(\mathrm{m}^{2} \cdot \mathrm{a}\right)$ (Figure $3 \mathrm{~b}$ ). However, $98 \%$ of the glaciers in the Tianshan Mountains are smaller than $10 \mathrm{~km}^{2}$, so glacial ablation will significantly impact regional water resources.

To elucidate the characteristics of glacial retreat in the Tianshan Mountains, the glacial retreat of 19 typical basins (or glaciers) was analysed (Figure 1). The results indicated that the annual average glacial retreat rate in the west is faster than that in the east during the 1960s/70s-2000 (Table 1), but the rate was faster in the east than that in the west during 2000-2010. Interestingly, likely bounded by the longitude of $79^{\circ} \mathrm{E}$, of the ten glaciers in the west, six glaciers were retreating faster during the $1960 \mathrm{~s} / 70 \mathrm{~s}-2000$ than they were in the 2000-2010 period, but the nine glaciers in the east were all retreating faster during 2000-2010 than they were in the 1960s/70s-2000 (Figure 1 and Table 1).

Table 1 Variations in glacier area in the typical river basins (or glaciers) of the Tianshan Mountains during the 1960s/70s-2010; the glacial serial number in this table is consistent with that in Figure 1

\begin{tabular}{|c|c|c|c|c|c|c|}
\hline ID & $\begin{array}{c}\text { Basins } \\
\text { (or glaciers) }\end{array}$ & $\begin{array}{c}1960 \mathrm{~s} / 70 \mathrm{~s}-2000 \\
\left(\mathrm{~km}^{2} / \mathrm{a}\right)\end{array}$ & $\begin{array}{c}2000-2010 \\
\left(\mathrm{~km}^{2} / \mathrm{a}\right)\end{array}$ & $\begin{array}{c}1960 \mathrm{~s} / 70 \mathrm{~s}-2000 \\
(\% / \mathrm{a}) \\
\end{array}$ & $\begin{array}{c}2000-2010 \\
(\% / a)\end{array}$ & Reference sources \\
\hline 1 & Pskem & -1.08 & -1.11 & -0.52 & -0.63 & $\begin{array}{l}\text { Narama et al., } \\
2010\end{array}$ \\
\hline 2 & Abramov & -0.02 & -0.01 & -0.08 & -0.04 & $\begin{array}{l}\text { Barandun et al., } \\
2015\end{array}$ \\
\hline 3 & Lower Nargn & -0.29 & -0.23 & -0.35 & -0.30 & $\begin{array}{l}\text { Kriegel et al., } \\
2013\end{array}$ \\
\hline 4 & At-BashiKirkasi & -1.06 & -0.13 & -0.70 & -0.10 & $\begin{array}{l}\text { Kriegel et al., } \\
2013\end{array}$ \\
\hline 5 & SE-Fergana & -0.66 & 0.00 & -0.27 & 0.00 & $\begin{array}{l}\text { Narama et al., } \\
2010\end{array}$ \\
\hline 6 & At-Bashy & -0.39 & -0.51 & -0.35 & -0.50 & $\begin{array}{l}\text { Narama et al., } \\
2010\end{array}$ \\
\hline 7 & Dzhetim & -6.12 & -4.51 & -1.15 & -1.10 & Hagg et al., 2013 \\
\hline 8 & Tuyuksuyskiy & -0.02 & -0.02 & -0.56 & -0.82 & $\begin{array}{l}\text { Zemp et al., 2012, } \\
2013\end{array}$ \\
\hline 9 & Lli-Kungoy & -2.19 & -2.83 & -0.35 & -0.50 & Narama et al., 2010 \\
\hline 10 & Akshiirak & -1.22 & -0.18 & -0.60 & -0.10 & Hagg et al., 2013 \\
\hline 11 & Karatal river & -1.71 & -1.17 & -0.86 & -0.96 & $\begin{array}{l}\text { Kaldybayev et al., } \\
2016\end{array}$ \\
\hline 12 & Tomr & -0.32 & -0.47 & -0.08 & -0.11 & Huai et al., 2015 \\
\hline
\end{tabular}


(Continued)

\begin{tabular}{|c|c|c|c|c|c|c|}
\hline ID & $\begin{array}{c}\text { Basins } \\
\text { (or glaciers) }\end{array}$ & $\begin{array}{c}1960 \mathrm{~s} / 70 \mathrm{~s}-2000 \\
\left(\mathrm{~km}^{2} / \mathrm{a}\right)\end{array}$ & $\begin{array}{c}2000-2010 \\
\left(\mathrm{~km}^{2} / \mathrm{a}\right)\end{array}$ & $\begin{array}{c}1960 s / 70 s-2000 \\
(\% / a)\end{array}$ & $\begin{array}{c}2000-2010 \\
(\% / a)\end{array}$ & $\begin{array}{c}\text { Reference } \\
\text { sources }\end{array}$ \\
\hline 13 & West & -11.24 & -13.85 & -0.50 & -0.65 & \multirow{4}{*}{$\begin{array}{l}\text { He } \text { et al., } 2015 ; \\
\text { Wang et al., } 2013\end{array}$} \\
\hline 14 & North & -1.47 & -3.52 & -0.44 & -1.10 & \\
\hline 15 & West-central & -0.73 & -0.72 & -1.33 & -1.51 & \\
\hline 16 & East-central & -4.87 & -8.61 & -0.88 & -1.71 & \\
\hline 17 & $\begin{array}{l}\text { Urumqi } \\
\text { glacier No. } 1\end{array}$ & -0.004 & -0.01 & -0.29 & -0.59 & $\begin{array}{l}\text { Zemp et al., } \\
\text { 2012, 2013; He et } \\
\text { al., 2015; Wang } \\
\text { et al., 2013 }\end{array}$ \\
\hline 18 & East & -0.38 & -0.80 & -0.31 & -0.68 & $\begin{array}{l}\text { He et al., 2015; } \\
\text { Wang et al., } 2013\end{array}$ \\
\hline 19 & Miaoergou & -0.01 & -0.03 & -0.34 & -0.80 & $\begin{array}{l}\text { Xie and Jiang, } \\
2014\end{array}$ \\
\hline
\end{tabular}

The glacier mass balance is strongly negative in the Tianshan Mountains. The Tuyuksuyskiy Glacier in the western region was analysed from 1957 to 2012, and the Urumqi River's No. 1 Glacier in the eastern region was analysed from 1980 to 2012 . The two glaciers are numbered 17 and 8 in Figure 1, respectively. The results show that the Tuyuksuyskiy Glacier exhibited a negative mass balance during 1957-2012, with an annual average mass balance of $-13.44 \mathrm{~mm} / \mathrm{a}$ (Figure $4 \mathrm{a}$ ). The Urumqi River's No. 1 glacier also exhibited a negative mass balance, with an average annual mass balance of $-17.18 \mathrm{~mm} / \mathrm{a}$ (Figure $4 \mathrm{~b}$ ). The cumulative mass balance results show that the Tuyuksuyskiy Glacier was thinned by approximately $25 \mathrm{~m}$ during 1957-2012 (Figure 4a), and the Urumqi River's No.1 glacier was thinned by approximately $15 \mathrm{~m}$ during 1980-2012 (Figure 4b).

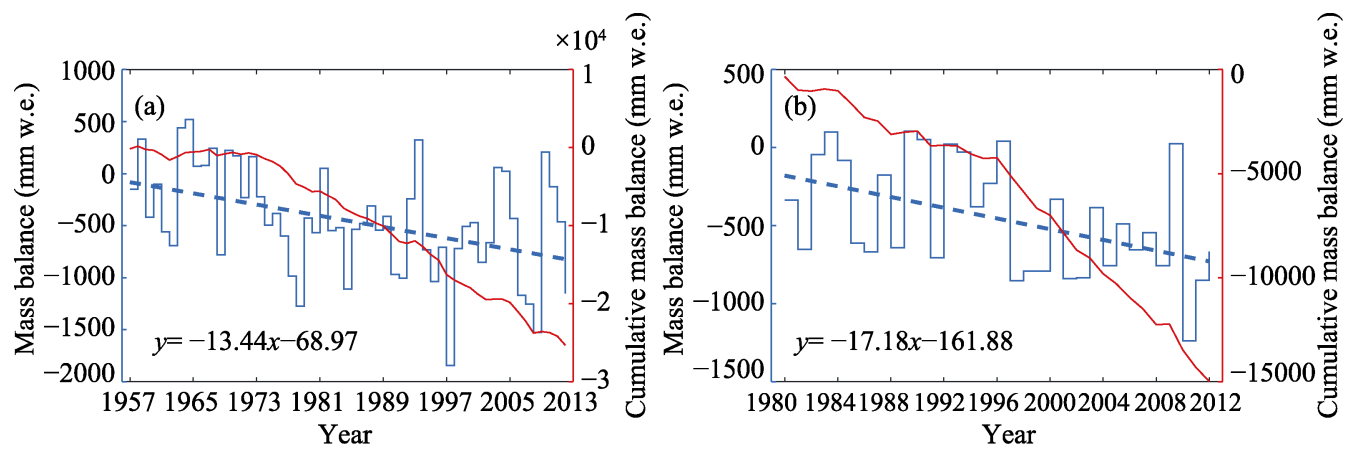

Figure 4 Analysis of glaciers mass balances, a) mass balance change of the Tuyuksuyskiy Glacier during 1957-2012; b) mass balance in the Urumqi Glacier No.1 during 1980-2012

\subsection{Snow cover changes}

Snow is an important part of the global cryosphere, and plays an important role in global climate change and the water and energy cycles. Snow coverage has a significant impact on the regional climate due to various factors, such as the energy exchange during the snow phase transition process, the adiabatic effect of the snow layer, and seasonal ablation and accumulation. There are large areas of seasonal and permanent snow cover in the Tianshan Mountains (Li et al., 2012). Therefore, a detailed analysis of snow coverage changes in the 
Tianshan Mountains is vital for understanding regional water resources changes.

Changes in snow cover are mainly caused by solar radiation in mountainous areas. According to the MODIS snow cover data, the largest extent of snow cover in the Tianshan Mountains generally occurs in January, and the smallest occurs in July. The maximum snow cover in 2004 was $84.9 \%$, while the minimum snow cover was $2.59 \%$ in 2009 (Figure 5). The maximum snow decreased at a rate of $0.44 \%$ /a from 2002 to 2013 , and the minimum snow cover also decreased at a rate of $0.01 \% / \mathrm{a}$ (equal to $-47 \mathrm{~km}^{2} / \mathrm{a}$ ) (Figure 5). The rapid decline of the maximum snow cover in the Tianshan Mountains is caused by the acceleration of snowpack melt and decrease in snowfall in low-elevation regions due to climate change.

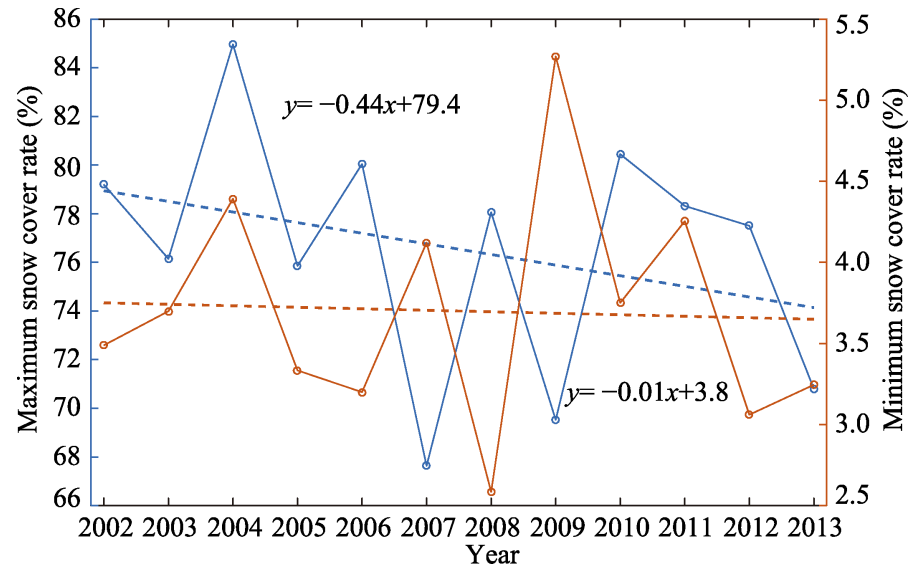

Figure 5 Variations in the maximum and minimum snow cover rates in Tianshan Mountains during 2002-2013

The duration of snow cover in the Tianshan Mountains, which is the length of time from the maximum snow cover to the minimum snow cover, i.e., the residence time of snow on the ground throughout the year, shortened. Snow cover acts as a buffer in the hydrological system and can mitigate the effects of climate change on hydrology. If the snow cover duration is long, then snow exerts a greater effect on the regulation of the hydrological system, while the opposite is also true. The results show that snow cover duration decreased by eight days, from 216 in 2002 to 208 in 2013 (Table 2). A shorter of snow cover duration weakens the buffering effect of snow on the hydrological system, increasing the variability of water resources in the Tianshan Mountains, which will have adverse effects on the utilisation of water resources in oasis regions.

Table 2 Days of snow cover in the Tianshan Mountains during 2002-2013. Max is the date of maximum snow cover in the year, Min is the date of minimum snow cover in the year, and days is the days between the maximum and minimum snow cover

\begin{tabular}{ccccccccc}
\hline Year & Max & Min & Days & Year & Max & Min & Days \\
\hline 2002 & 2002017 & 2002233 & 216 & 2008 & 2008049 & 2008209 & 160 \\
2003 & 2003065 & 2003249 & 184 & 2009 & 2009001 & 2009201 & 200 \\
2004 & 2004017 & 2001193 & 176 & 2010 & 2010041 & 2010225 & 184 \\
2005 & 2005001 & 2005209 & 208 & 2011 & 2011041 & 2011209 & 168 \\
2006 & 2006017 & 2006209 & 192 & 2012 & 2012017 & 2012225 & 208 \\
2007 & 2007001 & 2007201 & 200 & 2013 & 2013009 & 2013217 & 208 \\
\hline
\end{tabular}




\subsection{TWS variations}

\subsubsection{Spatiotemporal analysis}

There are significant spatial differences in the inter-annual changes in TWS in the Tianshan Mountains (Figure 6a). The decrease in TWS for most areas in the Tianshan Mountains is smaller than $-1 \mathrm{~cm} / \mathrm{a}$, but the central area exhibits a sharp decrease in TWS, reaching -8 to $-6 \mathrm{~cm} / \mathrm{a}$. This rate is alarming, and may be related to the sharp retreat of glaciers in this region (Deng and Chen, 2017).

The average rate of TWS decrease in the Tianshan Mountains during 2003-2015 was approximately $-0.7 \pm 1.53 \mathrm{~cm} / \mathrm{a}$ (Figure $6 \mathrm{~b}$ ), with an uncertainty of approximately $1-2 \mathrm{~cm}$. The main sources of uncertainty are measurement and leakage errors, and the effects of atmospheric quality disturbances and glacial mass rebound.
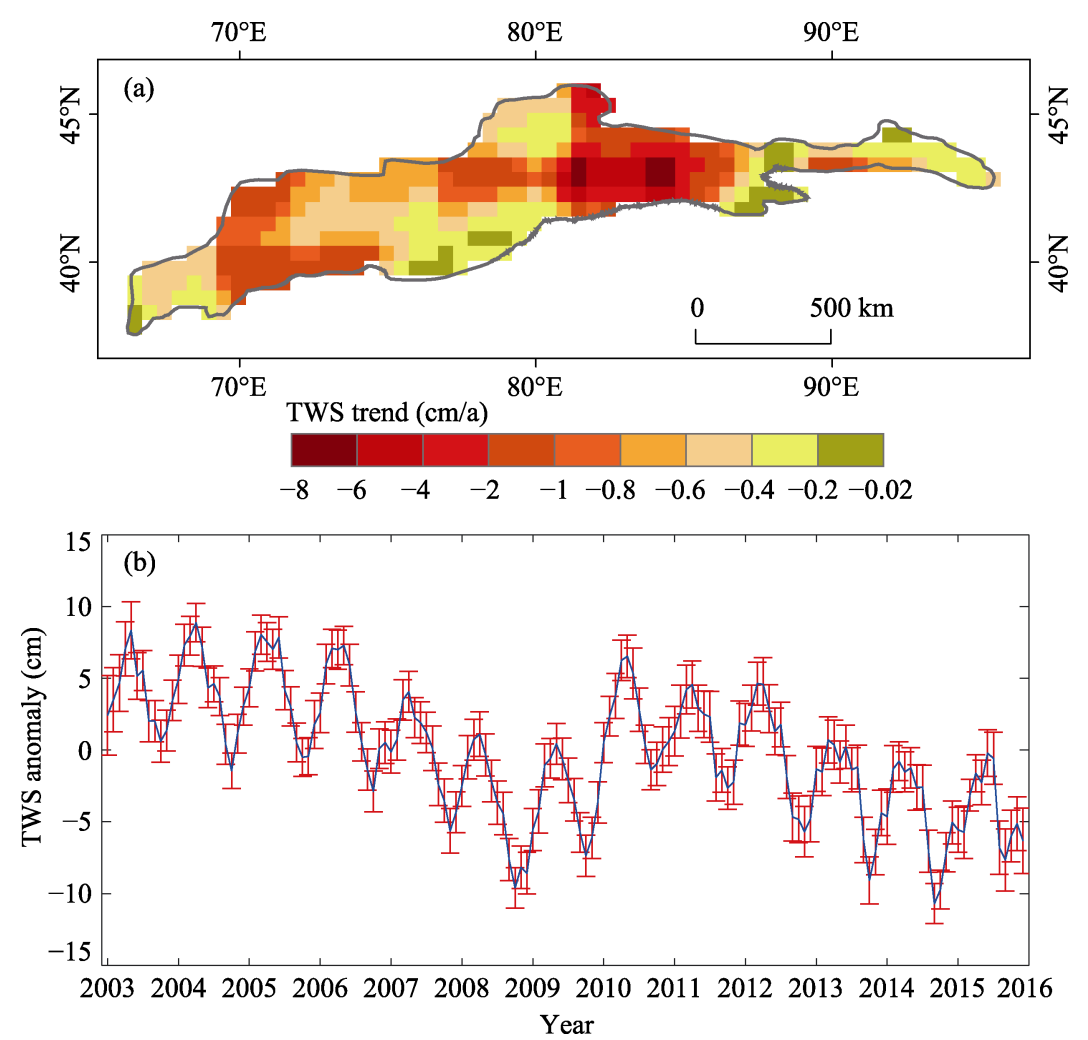

Figure 6 Variations in TWS in the Tianshan Mountains during 2003-2015 (a is the spatial variation of TWS, b is the time series of TWS, the blue line is the TWS-Mascons value, and the red line represents the uncertainty.)

Seasonal differences in the accumulation and ablation of glaciers and snow in mountainous areas have led to seasonal variations in TWS. The results of TWS in Figures 7a1 and 7a2 show positive anomalies in the spring and negative anomalies in the autumn. The positive anomaly of TWS in the spring is caused by the accumulation of the solid water body (i.e., glaciers and snow) during the winter; the maximum accumulation is reached in the spring, thus, this season exhibited a positive TWS anomaly. Similarly, ablation progressed in the summer and reached its maximum accumulation in the autumn, so TWS exhibited a negative anomaly in autumn. The winter and summer are in the transitional stages of positive and 
negative anomalies owing to the inter-annual differences in temperature and precipitation. Meanwhile, TWS decreased in all seasons due to the melting of glaciers and snow under global warming. Figure $7 \mathrm{~b}$ indicates that TWS in Tianshan Mountains mainly exhibited positive anomalies before 2007, but after 2013, the anomalies were mostly negative. Based on the inter-annual monthly changes, the TWS exhibits positive anomalies in the winter and negative anomalies in the summer. In addition, Figure $7 \mathrm{~b}$ shows that the inter-annual monthly trends of TWS anomalies are also decreasing.
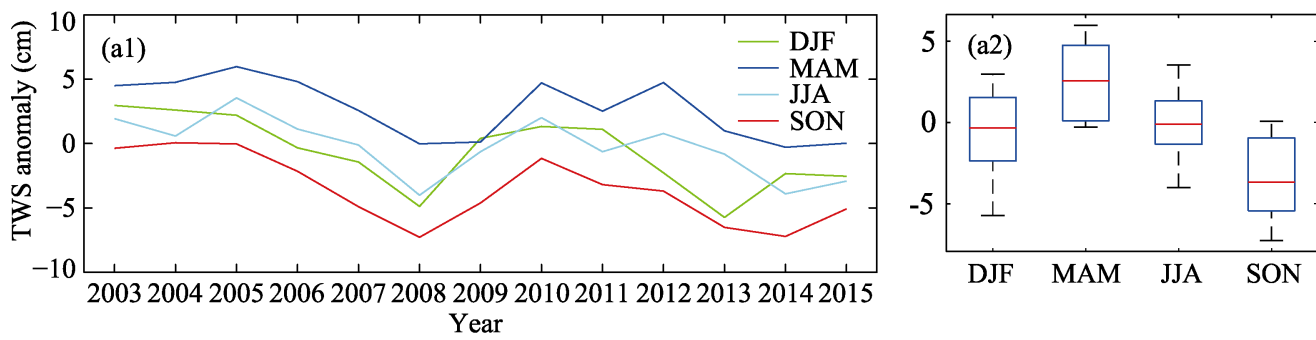

(b) TWS-Mascons

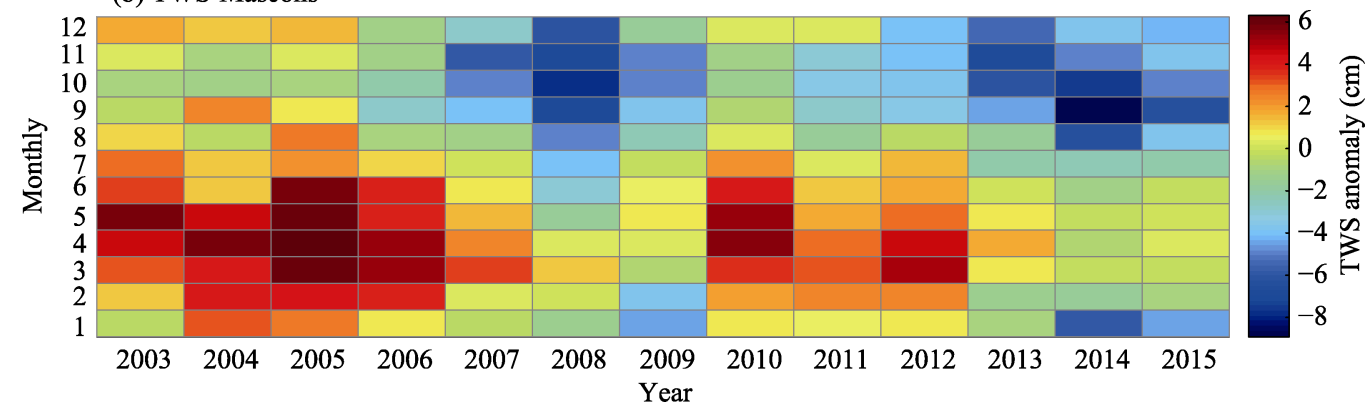

Figure 7 The TWS variations in the Tianshan Mountains at seasonal and monthly scales during $2003-2015$ (a1 and $\mathrm{a} 2$ show the seasonal scale, and b shows the monthly scale.)

\subsubsection{Cause diagnosis}

There are many observation stations in low-elevation regions, but few in the mountains. Therefore, we used the APHRO-Temperature dataset (Yatagai et al., 2012) to analyse temperature trends in the Tianshan Mountains. Figure 8a shows that the temperature is increasing in the east, at a rate of $0.02-0.04^{\circ} \mathrm{C} / \mathrm{a}$, while it is decreasing at a rate of $-0.016-0{ }^{\circ} \mathrm{C} / \mathrm{a}$ in the west.

The spatial differences in glaciers and snow changes are caused by spatial differences in temperature changes in the Tianshan Mountains (Figure 8). Glacier changes are more sensitive to temperature than precipitation in mountains (Liu et al., 1999; Sheng et al., 2009). The glacial retreat rate in the central area was -3.01 to $-1.2 \times 10^{3} \mathrm{~kg} /\left(\mathrm{m}^{2} \cdot \mathrm{a}\right)$, while that in the western area was -1.2 to $-0.4 \times 10^{3} \mathrm{~kg} /\left(\mathrm{m}^{2} \cdot \mathrm{a}\right)$. Some glaciers in the western part are increasing in size at a rate of 0 to $0.22 \times 10^{3} \mathrm{~kg} /\left(\mathrm{m}^{2} \cdot \mathrm{a}\right)$. Glaciers are the most important component of TWS in the Tianshan Mountains (Chen et al., 2016). Therefore, TWS decreased as the glaciers retreated, for example, the sharp glacial retreat in the central region (Figure 8b) caused the TWS change rate reach -7.95 to $-4 \mathrm{~cm} / \mathrm{a}$ (Figure $8 \mathrm{c}$ ). Although warming is more rapid in the east (Figure 8a), the declining rate of TWS is relatively small (Figure 8c) as the glaciers cover a small area while the others exist at higher elevations (Li et al., 2014). 
Therefore, even if the temperature is increasing, glacial retreat is relatively slow under warming, the decline in TWS is also slow.
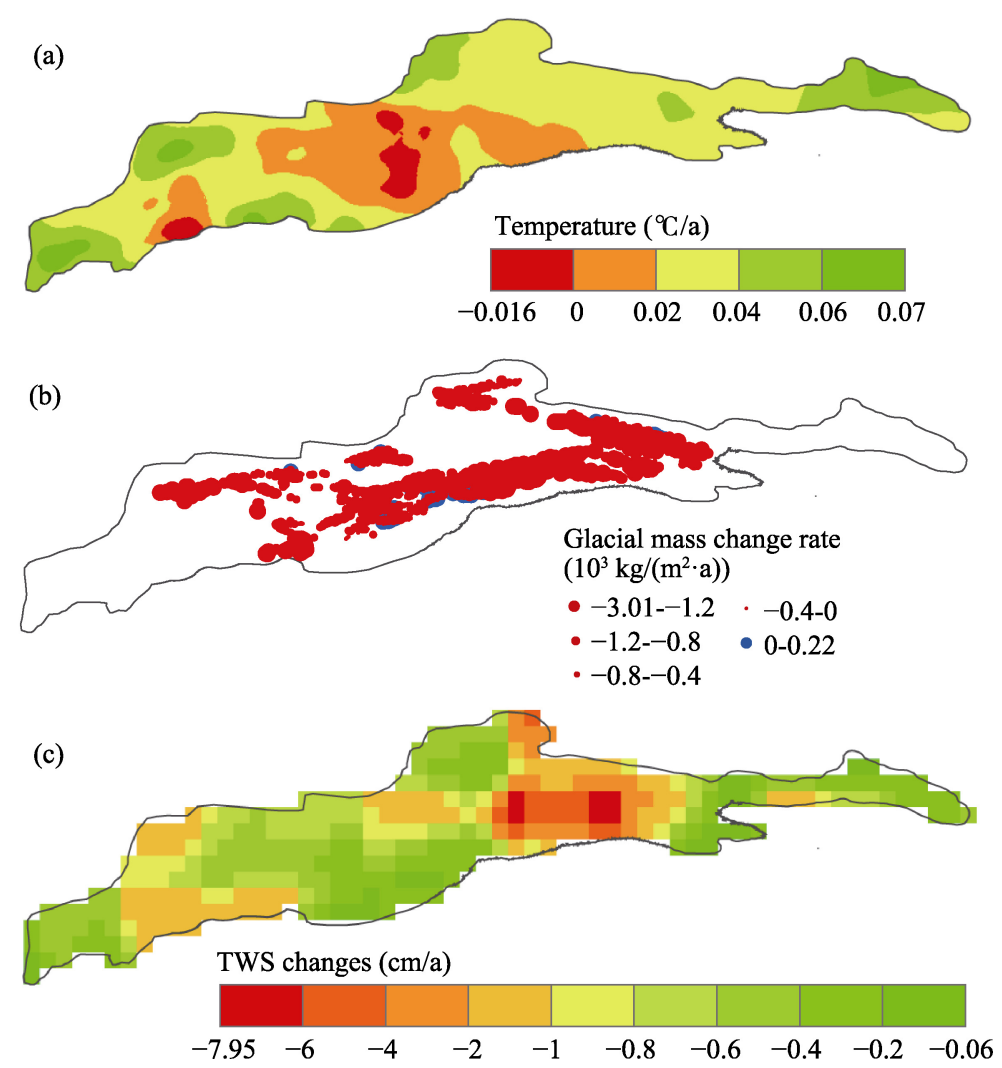

Figure 8 Variations in annual mean temperature, glaciers, and TWS in the Tianshan Mountains (a is the variation in annual mean temperature during 1961-2010, b is the glacier mass balance change rate during 1961-2012, and $\mathrm{c}$ is the variations in TWS during 2003-2015.)

\subsection{Variations in runoff}

The CV values in Table 3 for all three basins are between $0.1-0.2$, which is in accordance with the range of CV values for rivers supplied by glaciers and snowmelt (Yang, 1981). The glaciers and snow meltwater regulate variations in runoff in mountainous basins. The larger the proportion of glaciers in the whole basin, the more stable the inter-annual change in runoff. The results in Table 3 show that the glacier area accounted for 3.8\% of the total Aksu River Basin, 2.2\% of the total Kaidu River Basin, and 2.75\% of the total Urumqi River Basin. The corresponding $\mathrm{Cv}$ value of the Kaidu River is large, while those of the Aksu and Urumqi rivers are relatively small.

Table 3 Characteristics of runoff in the three typical river basins

\begin{tabular}{cccccc}
\hline Basins & $\begin{array}{c}\text { Area } \\
\left(10^{4} \mathrm{~km}^{2}\right)\end{array}$ & $\begin{array}{c}\text { (Glacier area/basin } \\
\text { area }) * 100 \%\end{array}$ & $\begin{array}{c}\text { Annual average } \\
\text { runoff }\left(10^{8} \mathrm{~m}^{3}\right)\end{array}$ & Runoff sd $\left(10^{8} \mathrm{~m}^{3}\right)$ & $\mathrm{Cv}$ value \\
\hline Aksu River & 4.1932 & $3.8 \%$ & 76.15 & 11.61 & 0.15 \\
Kaidu River & 1.8631 & $2.2 \%$ & 35.53 & 6.78 & 0.19 \\
Urumqi River & 0.1114 & $2.75 \%$ & 7.93 & 1.09 & 0.14 \\
\hline
\end{tabular}


The runoff volume in the three basins increased from 1960 to 2010 . Among them, the Aksu River Basin exhibited the largest increase rate of $0.4 \times 10^{8} \mathrm{~m}^{3} / \mathrm{a}(\mathrm{p}<0.01$, Figure 9a1), followed by the Kaidu (Figure 9b1) and Urumqi river basins, which exhibited the smallest increase rate of $0.04 \times 10^{8} \mathrm{~m}^{3} / \mathrm{a}(\mathrm{p}<0.01$, Figure 9c1). This is because the Urumqi River has the smallest basin area of these three sites. The first and second glacier cataloging datasets of China can be used to analyse the glacial area changes in the Aksu (the Chinese part), Kaidu, and Urumqi river basins over the past 50 years. The results show that the glacial area decreased by $29.7 \%$ in the Aksu River Basin, while those of the Kaidu and Urumqi river basins decreased by almost $64 \%$ and $57.7 \%$, respectively. Therefore, the increase in the runoff volume of the three river basins was caused by the increase in glacier meltwater. However, runoff volume has been decreasing in the three river basins since the mid-1990s (Figures $9 \mathrm{a} 1,9 \mathrm{~b} 1$, and 9c1).
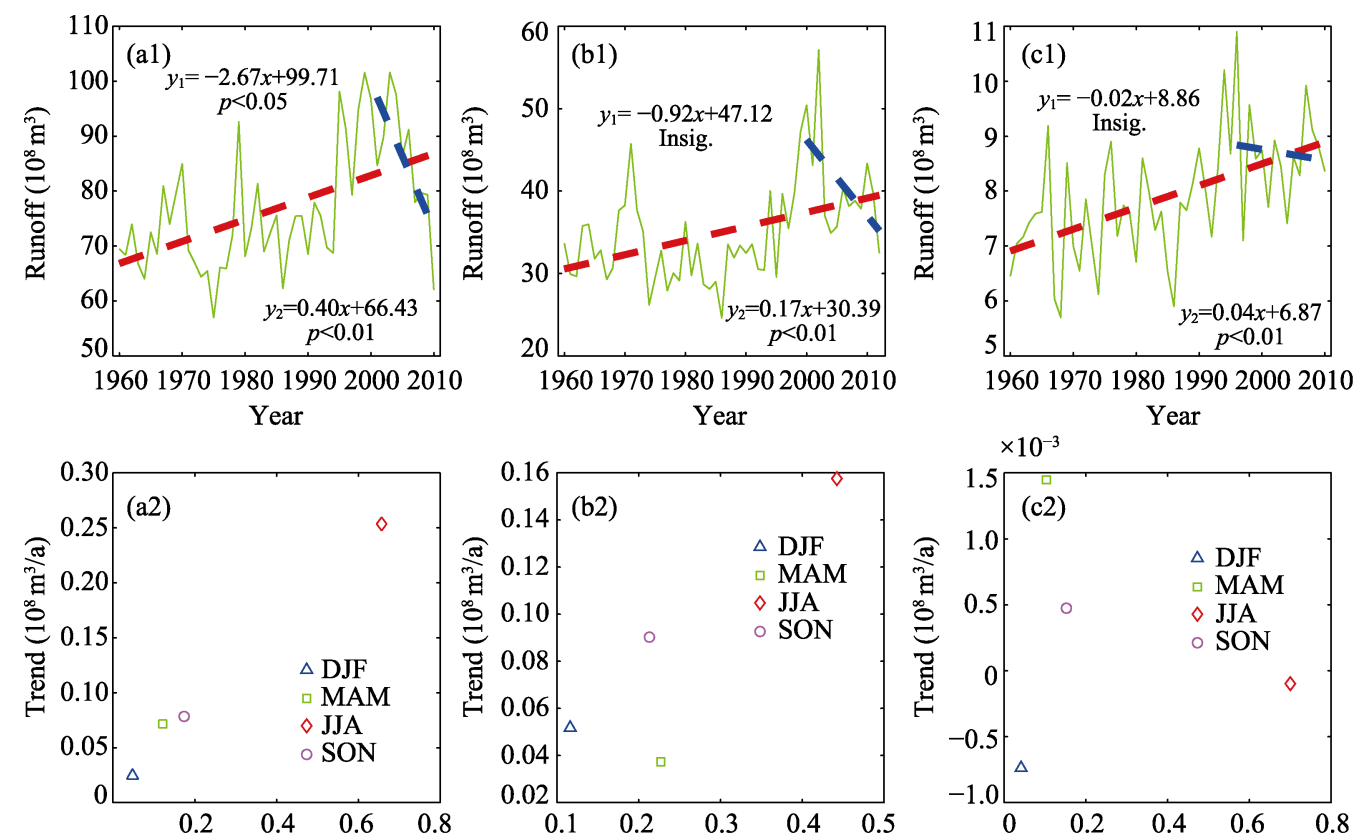

Ratio of seasonal to annual runoff

Ratio of seasonal to annual runoff

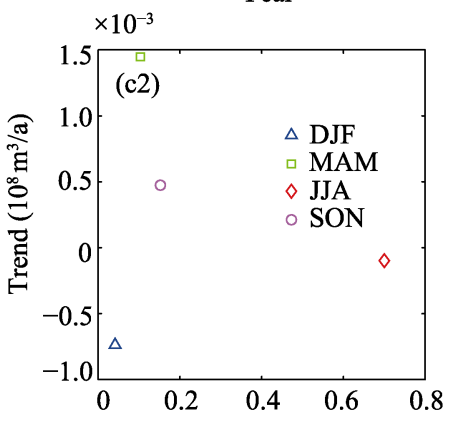

Figure 9 Runoff changes in the Aksu (a1, a2), Kaidu (b1, b2), and Urumqi (c1, c2) river basins during 1960-2010. a1, b1, and c1 refer to the annual runoff changes; a2, b2, and c2 refer to the seasonal runoff changes and the ratio of seasonal to annual runoff

Summer runoff is the largest component of annual runoff in the three river basins. The Aksu (Figure 9a2) and Urumqi (Figure 9c2) river basins exhibit the ratio of seasonal to annual runoff are all above 0.6, while that of the Kaidu River Basin is below 0.5 (Figure 9b2) because both of the greater and smaller Youledousi basins in the headwaters of the Kaidu River Basin regulate runoff. The increase in the summer runoff of the Aksu (Figure 9a2) and the Kaidu (Figure 9b2) river basins are mainly caused by the increase in glacial meltwater, however, summer runoff in the Urumqi River Basin is slightly decreasing (Figure 9c2). By comparing the first and second glacial catalogue data, the area covered by glaciers in the Urumqi River Basin decreased by 57.7\% (Figure 10a), and small glaciers almost disappeared. We also analysed the equilibrium line altitude (ELV) and mass balance of the Urumqi Glacier No. 1; the results show that the elevation of ELV increased from 1980 to 
2012 at a rate of $3.8 \mathrm{~m} / \mathrm{a}$ (Figure 10b), and the mass balance was strongly negative (Figure 10c). The Urumqi Glacier No.1 thinned by $15 \mathrm{~m}$ from 1980 to 2012 (Figure 4b). Therefore, the decrease in summer runoff in the Urumqi River Basin is due to the decrease in glacier meltwater caused by the reduction in the area (Figure 10a), increase in the ELV (Figure 10b), and thinning of the glacier (Figure 10c).
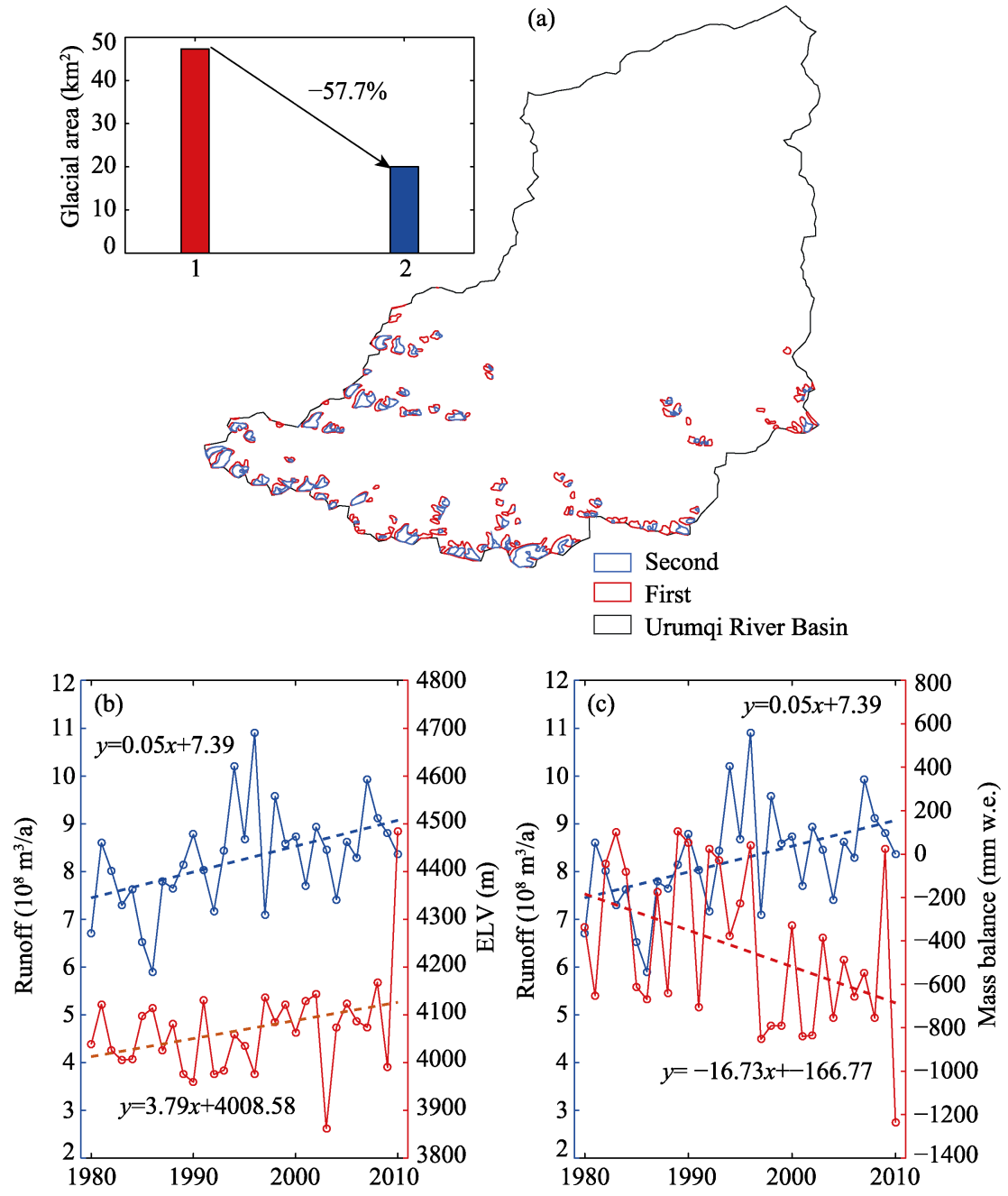

Figure 10 Relationship between glacier characteristic variations and runoff changes in the Urumqi River Basin. (a. glacial variation based on the first and second glacier inventories of China; b. comparison of changes in runoff and the ELV of the Urumqi Glacier No.1; c. comparison of the changes in runoff and mass balance of the Urumqi Glacier No.1)

\section{Conclusions}

Glaciers and snow are the main constituents of the solid water body in the Tianshan Mountains, and they are continuously declining. Our results indicated that small glaciers are more sensitive to climate change. The highest glacial retreat rate of $-2.3 \times 10^{3} \mathrm{~kg} /\left(\mathrm{m}^{2} \cdot \mathrm{a}\right)$ occurred at elevations below $3000 \mathrm{~m}$. Snow cover also exhibited a decreasing trend, and the snow cover duration was shortened. 
The rapid retreat of glaciers has accelerated the reduction in the TWS of the Tianshan Mountains, which decreased from 2003 to 2015 at $0.7 \pm 1.53 \mathrm{~cm} / \mathrm{a}$. The maximum rate of the TWS decrease is -8 to $-6 \mathrm{~cm} / \mathrm{a}$ in the central area of the Tianshan Mountains, which is consistent with the sharp retreat of glaciers in this region.

There is a close relationship between variations in runoff characteristics and glacial changes in the basins. Runoff increased in the three typical river basins from 1960 to 2010 due to the increase in glacial meltwater. However, runoff has decreased in the three typical river basins since the mid-1990s due to the significant retreat of glaciers.

\section{References}

Aizen V, Aizen E, Surazakov A et al., 2008. Is Central Asia really exsiccated? In: Proceedings of AGU Fall Meeting, San Francisco, GC53C-07.

Aizen V, 2011. Tien Shan Glaciers. In: Singh V P, Singh P, Haritashya U K. Encyclopedia of Snow, Ice and Glaciers. Dordrecht and Netherlands: Springer, pp.1179.

Barandun M, Huss M, Sold L et al., 2015. Re-analysis of seasonal mass balance at Abramov Glacier 1968-2014. Journal of Glaciology, 61(230): 1103-1117.

Berghuijs W, Woods R, Hrachowitz M et al., 2014. A precipitation shift from snow towards rain leads to a decrease in streamflow. Nature Climate Change, 4(7): 583-586.

Chen J, Wilson C R, Tapley B D et al., 2009. 2005 drought event in the Amazon River basin as measured by GRACE and estimated by climate models. Journal of Geophysical Research: Solid Earth, 114(B5): B05404.

Chen J L, Rodell M, Wilson C R et al., 2005. Low degree spherical harmonic influences on Gravity Recovery and Climate Experiment (GRACE) water storage estimates. Geophysical Research Letters, 32: L14405.

Chen Y N, Li W H, Deng H J et al., 2016. Changes in Central Asia's Water Tower: Past, present and future. Scientific Reports, 6: 35458.

Chen Y N, Li Z, Fang G H et al., 2017. Impact of climate change on water resources in the Tianshan Mountains, Central Asia. Acta Geographica Sinica, 72(1): 18-26. (in Chinese)

Cheng M, Tapley B D, Ries J C, 2013. Deceleration in the Earth's oblateness. Journal of Geophysical Research: Solid Earth, 118: 740-747.

Deng H J, Chen Y N, 2017. Influences of recent climate change and human activities on water storage variations in Central Asia. Journal of Hydrology, 544: 46-57.

Deng H J, Pepin N, Chen Y N, 2017. Changes of snowfall under warming in the Tibetan Plateau. Journal of Geophysical Research: Atmospheres, 122(14): 7323-7341.

Farinotti D, Longuevergne L, Moholdt G et al., 2015. Substantial glacier mass loss in the Tien Shan over the past 50 years. Nature Geoscience, 8(9): 716-722.

Gao X, Ye B S, Zhang S Q et al., 2010. Glacier runoff variation and its influence on river runoff during 1961-2006 in the Tarim River Basin, China. Science China: Earth Science, 40(5): 654-665. (in Chinese)

Geruo A, Wahr J, Zhong S, 2013. Computations of the viscoelastic response of a 3-D compressible Earth to surface loading: An application to glacial isostatic adjustment in Antarctica and Canada. Geophysical Journal International, 192(2): 557-572.

Guo F X, Xiao Y, Wang F F, 2014. Mascon inversion method of earth surface mass anomaly using GRACE range rate data. Progress in Geophysics, 29(6): 2494-2497. (in Chinese)

Guo W Q, Xu J L, Liu S Y et al., 2014. The Second Glacier Inventory Dataset of China (Version 1.0). Cold and Arid Regions Science Data Center at Lanzhou. doi: 10.3972/glacier.001.2013.db.

Hagg W, Mayer C, Lambrecht A et al., 2013. Glacier changes in the Big Naryn basin, Central Tian Shan. Global and Planetary Change, 110, Part A, 40-50.

Hansen J, Makiko S, Reto R et al., 2006. Global temperature change. Proceedings of the National Academy of Sciences, 103(39): 14288-14293. 
He Y, Yang T B, Ji Q et al., 2015. Glacier variation in response to climate change in Chinese Tianshan Mountains from 1989 to 2012. Journal of Mountain Science, 12(5): 1189-1202.

Hirsch R, Slack J, 1984. A nonparametric trend test for seasonal data with serial dependence. Water Resources Research, 20(60): 727-732.

Huai B, Li Z, Sun M et al., 2015. Change in glacier area and thickness in the Tomur Peak, western Chinese Tien Shan over the past four decades. Journal of Earth System Science, 124(2): 353-363.

Immerzeel W, Beek L, Bierkens P, 2010. Climate change will affect the Asian water towers. Science, 328(5984): $1382-1385$.

Jacob T, Wahr J, Pfeffer T et al., 2012. Recent contributions of glaciers and ice caps to sea level rise. Nature, 482(7386): 514-518.

Kaldybayev A, Chen Y, Vilesov E, 2016. Glacier change in the Karatal river basin, Zhetysu (Dzhungar) Alatau, Kazakhstan. Annals of Glaciology, 57(71): 11-19.

Kriegel D, Mayer D, Hagg W et al., 2013. Changes in glacierisation, climate and runo in the second half of the 20th century in the Naryn basin, Central Asia. Global Planetary Change, 110: 1-61.

Lee H, Beighley R E, Alsdorf D et al., 2011. Characterization of terrestrial water dynamics in the Congo Basin using GRACE and satellite radar altimetry. Remote Sensing of Environment, 115(12): 3530-3538.

Li B F, Chen Y N, Chen Z S et al., 2012. The effect of climate change during snowmelt period on streamflow in the mountains areas of Northwest China. Acta Geographica Sinica, 67(11): 1461-1470. (in Chinese)

Li J, Yang T B, He Y et al., 2014. Response of glacier retreat to climate in Eastern Tianshan from 1990-2011. Research of Soil and Water Conservation, 21(3): 212-216. (in Chinese)

Li X Y, 1982. Regularity of perennial variations in annual runoff for northeastern China and its prognosis. Scientia Geographica Sinica, 2(3): 238-246. (in Chinese)

Liu S Y, Sun W X, Shen Y P et al., 2003. Glacier changes since the Little Ice Age maximum in the western Qilian Shan, Northwest China, and consequences of glacier runoff for water supply. Journal of Glaciology, 49(164): $117-124$.

Liu S Y, Wang N L, Ding Y J et al., 1999. On the characteristics of glacier fluctuations during the last 30 years in Urumqi River Basin and the estimation of temperature rise in the high mountain area. Advance in Earth Sciences, 14(3): 279-285. (in Chinese)

Liu S Y, Yao X J, Guo W Q et al., 2015. The contemporary glaciers in China based on the Second Chinese Glacier Inventory. Acta Geographica Sinica, 70(1): 3-16. (in Chinese)

Long D, Yang Y T, Wada Y et al., 2015. Deriving scaling factors using a global hydrological model to restore GRACE total water storage changes for China's Yangtze River Basin. Remote Sensing of Environment, 168: 177-193.

Lutz A, Immerzeel W, Shrestha A et al., 2014. Consistent increase in High Asia's runoff due to increasing glacier melt and precipitation. Nature Climate Change, 4: 587-592.

Matsuo K, Heki K, 2010. Time-variable ice loss in Asian high mountains from satellite gravimetry. Earth and Planetary Science Letters, 290(1/2): 30-36.

Mountain Research Initiative (MRI), 2015. Elevation-dependent warming in mountain regions of the world. Nature Climate Change, 5(5): 424-430.

Narama C, Kääb A, Duishonakunov M et al., 2010. Spatial variability of recent glacier area changes in the Tien Shan Mountains, Central Asia, using Corona ( 1970), Landsat ( 2000), and ALOS ( 2007) satellite data. Global Planetary Change, 71(1/2): 42-54.

Paul F, Bolch T, Kaab A et al., 2015. The glaciers climate change initiative: Methods for creating glacier area, elevation change and velocity products. Remote Sensing of Environment, 162: 408-426.

Pfeffer W, Arendt A, Bliss A et al., 2014. The Randolph Glacier Inventory: A globally complete inventory of glaciers. Journal of Glaciology, 60(221): 537-552.

Rodell M, Famiglietti J, Chen J et al., 2004. Basin scale estimates of evapotranspiration using GRACE and other observations. Geophysical Research Letters, 31(20): L20504.

Rodell M, Velicogna I, Famiglietti J, 2009. Satellite-based estimates of groundwater depletion in India. Nature, 
460(7258): 999-1002.

Schmidt R, Schwintzer P, Flechtner F et al., 2006. GRACE observations of changes in continental TWS. Global Planetary Change, 50(1/2): 112-126.

Sen P, 1968. Estimates of the regression coefficient based on Kendall's Tau. Journal of the American Statistical Association, 63(324): 1379-1389.

Shen Y P, Wang G Y, Ding Y J et al., 2009. Changes in glacier mass balance in watershed of Sary Jaz-Kumarik rivers of Tianshan Mountains in 1957-2006 and their impact on water resources and trend to end of the 21st century. Journal of Glaciology and Geocryology, 31(5): 792-800. (in Chinese)

Swenson S, Chambers D, Wahr J, 2008. Estimating geocenter variations from a combination of GRACE and ocean model output. Journal of Geophysical Research, 113: B08410.

Wahr J, Molenarr M, 1998. Time variability of the earth's gravity field: Hydrological and oceanic effects and their possible detection using GRACE. Journal of Geophysical Research: Solid Earth, 103(B12): 30205-30229.

Wahr J, Swenson S, Velicogna I, 2006. Accuracy of GRACE mass estimates. Geophysical Research Letters, 33(6): L06401.

Wang P Y, Li Z Q, Wang W B et al., 2013. Changes of six selected glaciers in the Tomor region, Tian Shan, Central Asia, over the past $\sim 50$ years, using high-resolution remote sensing images and field surveying. Quaternary International, 311: 123-131.

Watkins M, Wiese D N, Yuan D N et al., 2015. Improved methods for observing Earth's time variable mass distribution with GRACE using spherical cap mascons. Journal of Geophysical Research: Solid Earth, 120: 2648-2671.

Xavier L, Becker M, Cazenave A et al., 2010. Interannual variability in water storage over 2003-2008 in the Amazon Basin from GRACE space gravimetry, in situ river level and precipitation data. Remote Sensing of Environment, 114(8): 1629-1637.

Xie W, Jiang F Q, 2014. Change trend of glaciers in the Hami region. Arid Zone Research, 31(1): 27-31. (in Chinese)

Xu C C, Chen Y N, Chen Y P et al., 2013. Responses of surface runoff to climate change and human activities in the arid region of Central Asia: A case study in the Tarim River Basin, China. Environmental Management, 51(4): 926-938.

Yang Z N, 1981. Mountain stream types in Northwest China. Journal of Glaciology and Geocryology, 3(2): 14-31. (in Chinese)

Yao J Q, Yang Q, Hu W F et al., 2013. Characteristics analysis of water vapor contents around Tianshan Mountains and the relationships with climate factors. Scientia Geographica Sinica, 33(7): 859-864. (in Chinese)

Yatagai A, Kamiguchi K, Arakawa O et al., 2012. APHRODITE: Constructing a long-term daily gridded precipitation dataset for Asia based on a dense network of rain gauges. Bulletin of the American Meteorological Society, 93(9): 1401-1415.

Zemp M, Frey M, Gartne-Roer H et al., 2012. WGMS: Fluctuations of Glaciers 2005-2010 (Vol.X).

Zemp M, Nussbaumer M, Naegeli K et al., 2013. WGMS: Glacier Mass Balance Bulletin No.12 (2010-2011).

Zou X C, Jin T Y, Zhu G B, 2016. Research on the MASCON method for the determination of local surface mass flux with satellite-satellite tracking technique. Chinese Journal of Geophysics, 59(12): 4623-4632. (in Chinese) 